\title{
Judicial serendipity: how Portuguese judges came to the rescue of the Polish judiciary
}

\author{
ECJ 27 February 2018, Case C-64/16, Associação Sindical dos \\ Juizes Portugueses
}

\author{
Matteo Bonelli* \& Monica Claes**
}

\section{INTRODUCTION}

While trying to defend their salaries from austerity measures, a group of Portuguese judges may have accidentally stumbled upon a way to judicially safeguard the rule of law and the independence of the judiciary throughout the European Union. Referred from Lisbon to Luxembourg, where it was decided by the Court of Justice of the European Union, the case discussed in this contribution may have its most significant impact in Warsaw and perhaps also in Budapest, capitals of the two Member States most often accused of threatening the basic values of the $\mathrm{EU}$ in recent years.

The judgment of the Court delivered in February $2018^{1}$ was as groundbreaking as it was surprising, even if the outcome itself was predictable. The Court decided that the second subparagraph of Article 19(1) TEU must be interpreted as meaning that the principle of judicial independence does not preclude a temporary reduction in the remuneration paid to members of the Portuguese Tribunal de Contas (Court of Auditors) in the context of austerity measures linked to an EU financial assistance programme. While the final decision could easily have been anticipated - temporary pay reductions in the context of austerity have been accepted by the Court of Justice and other courts in the past ${ }^{2}-$ the very fact that the

* PhD researcher, Faculty of Law, Maastricht University.

** Professor of European and Comparative Constitutional Law, Faculty of Law, Maastricht University.

${ }^{1}$ ECJ 27 February 2018, Case C-64/16, Associação Sindical dos Juizes Portugueses.

${ }^{2}$ On the Court of Justice and the Portuguese Constitutional Court's case law on austerity, see infra. See also ECtHR Second Section, 8 October 2013, Application Nos. 62235/12 and 57725/12, 
Court of Justice assumed jurisdiction in this case and took the second subparagraph of Article 19(1) TEU on board is remarkable. In fact, the Court stretched the reach of EU law to an extreme, bringing virtually the entire national judicial organisation under its purview. Indeed, the decision suggests that Article 19(1) TEU, which states that 'the Member States shall provide remedies sufficient to ensure effective legal protection in the fields covered by Union law', brings all legislation affecting those national judges who may be asked to apply EU law under the purview of the Court of Justice. Accordingly, the Member States must ensure those judges' judicial independence, a principle that is said to be inherent to Article 19 TEU. That provision thus serves two aims: it brings national judiciaries that may potentially act as European judges under the jurisdiction of the Court, and it sets the standard for review, i.e. it is the source of the principle of judicial independence.

The political objectives of the Court's decision are clear: Luxembourg wants to clarify that the organisation of the national judiciaries is not exclusively a matter for each of the Member States separately, but that Member States are under an obligation, contained in primary EU law and supervised by the Court of Justice, to ensure that their courts and judges are independent in the fields covered by EU law'. We will argue in the following pages that the key to understanding the ruling is the Court's desire to have a say in the current situation in Poland and Hungary where, after the adoption of controversial constitutional and institutional reforms, the independence of the national judiciaries has been called into question. The Court, until now almost marginalised in the discussion, creates for itself an opportunity to intervene in the debate and in particular to assess, on the basis of primary EU law, recent amendments to the laws regulating the functioning of Polish courts. In order to achieve this result, the Court of Justice unexpectedly ${ }^{3}$ transformed a case that initially seemed to be about judicial review of austerity measures ${ }^{4}$ into a decision on the organisation of the European judicial system. Or, looking at the ruling from a different perspective, it shifted the focus from the economic crisis (or Eurocrisis) to the 'rule of law crisis'.

This case note begins with what was the background of the decision, briefly summarising the previous case law of the Court of Justice and of the Portuguese

António Augusto Da Conceição Mateus v Portugal and Lino Jesus Santos Januário v Portugal, in which the ECtHR held that, in light of the exceptional economic and financial crisis faced by Portugal at the material time and given the limited extent and the temporary effect of the reduction of their holiday and Christmas subsidies (only valid for one year, because they were established in a State Budget Law), the applicants did not bear a disproportionate and excessive burden, and therefore found the applications inadmissible.

${ }^{3}$ As proved by the fact that only the Commission and Portugal intervened in the case.

${ }^{4}$ As explained in the following pages, this was also the approach followed by AG Øe in his Opinion. 
Constitutional Court on austerity measures, and discussing the facts of the case and the procedure before the Portuguese court. Then, the contribution analyses the decision of the Luxembourg Court, illustrating the creative construction, first, of the scope of EU law, second, of the principle of effective judicial protection, and finally of judicial independence as an EU law obligation, all on the basis of Article 19 TEU. The fourth section explains why the decision can better and perhaps only be understood in the context of the rule of law battle between the EU and Poland, and reflects on how the ruling might influence future $\mathrm{EU}$ actions in protection of the rule of law. Finally, the last section reflects more broadly on the idea of a 'European judiciary', which the Court seems to be building with this ruling and that also emerges from the decision delivered in Achmea. ${ }^{5}$

\section{The Background of the CaSe: Portugal and austerity Measures}

In spring 2011, Portuguese authorities began implementing, at the domestic level, a series of austerity measures adopted to fulfil the obligations agreed with the European Commission in the Memorandum of Understanding concluded in May 2011, and its successive amendments. ${ }^{6}$ The Memorandum contained the specific economic conditions for the conferral of EU financial assistance to Portugal under the European Financial Stabilisation Mechanism (the so-called EFSM).

\section{Portuguese austerity measures before national courts and the Court of Justice}

Many of these austerity measures have been challenged before Portuguese courts, including the Constitutional Court, on numerous occasions. The Constitutional Court has declared several of them, including pay cuts for civil servants, unconstitutional. ${ }^{8}$ These cases were typically decided on the basis of the principles of equality and legitimate expectations as laid down in Portuguese constitutional law. The Constitutional Court chose to restrict its analysis to Portuguese legislation, using

${ }^{5}$ ECJ 6 March 2018, Case C-284/16, Achmea.

${ }^{6}$ The first Memorandum was signed on 17 May 2011: see Memorandum of Understanding on Specific Economic Policy Conditionality between the Portuguese State and the European Commission, available at <www.portugal.gov.pt/media/371369/mou_20110517.pdf>, visited 31 July 2018.

${ }^{7}$ See also Council Implementing Decision 344/2011. As prescribed by Art. 136(3) TFEU, EU financial assistance is dependent on strict economic policy conditionality.

${ }^{8}$ For an overview of the decisions of the Portuguese courts, see M. Canotilho et al., 'Austerity measures under judicial scrutiny: the Portuguese constitutional case-law', 11 Eu Const (2016) p. 155; A.M. Guerra Martins, 'Constitutional Judge, Social Rights and Public Debt Crisis - The Portuguese Constitutional Case Law, 22(5) Maastricht Journal of European and Comparative Law (2015) p. 678; F. Pereira Coutinho, 'Austerity on the loose in Portugal: European judicial restraint in times of crisis', 8(3) Perspectives on Federalism (2016). 
as a standard of reference only the Portuguese Constitution, and did not engage in a judicial dialogue with the Court of Justice on the topic, as it could have done, for example, by raising questions on the validity the Memorandum of Understanding. ${ }^{9}$

Lower courts on the other hand did ask the Court of Justice to review the compatibility of Portuguese austerity measures with EU law and the Charter. But Luxembourg consistently sought to deny jurisdiction, declaring inadmissible those references that raised questions about the conformity of austerity measures with EU fundamental rights. References relating to public sector salary cuts and welfare benefit reductions from countries on financial assistance programmes were thus not dealt with in substance. ${ }^{10}$ Recalling that, in the context of the preliminary ruling procedure, the Court can only interpret EU law within the limits of the competences attributed to the $\mathrm{EU}$, and that the Charter only applies when the Member States are implementing EU law, the Court motivated those decisions by holding that the referring courts had not explained why the relevant piece of legislation should be seen as 'implementing EU law'. ${ }^{11}$

\section{The facts of the case: an austerity case?}

At first sight, the case discussed in this contribution seemed to be part of this growing line of EU austerity cases. The request for a preliminary ruling by the Supremo Tribunal Administrativo had been submitted in proceedings between the Associação Sindical dos Juizes Portugueses (a trade union of Portuguese Judges, hereinafter 'the trade union') and the Tribunal de Contas. The proceedings concerned a reduction in salaries paid to the members of the latter court, which resulted from Law 75/2014 that temporarily reduced remuneration in the public

${ }^{9}$ Critical on the Portuguese Constitutional Court's approach: Coutinho, supra n. 8; on the other hand, defending the position of the Court in which she served during the 'austerity case law', Guerra Martins, supra n. 8.

${ }^{10}$ ECJ 7 March 2013, Case C-128/12, Sindicato dos Bancários do Norte and Others v BPN-Banco Português de Negócios SA; see also ECJ 26 June 2014, Case C-264/12, Sindicato Nacional dos Profissionais de Seguros e Afins v Fidelidade Mundial - Companhia de Seguros SA; ECJ 21 October 2014, Case C-665/13, Sindicato Nacional dos Profissionais de Seguros e Afins v Via Directa Companhia de Seguros SA. See also the Romanian cases: ECJ 14 December 2011, Case C-434/11, Corpul Naţional al Poliţiştilor v Ministerul Administraţiei şi Internelor (MAI) and Others; ECJ 10 May 2012, Case C-134/12, Corpul Naţional al Poliţistilor Ministerul Administraţiei şi Internelor and Others; ECJ 15 November 2012, Case C-369/12, Corpul Naţional al Poliţţstilor - Biroul Executiv Central, reprezentant al reclamanților Chiţea Constantin şi alţii v Ministerul Administraţiei ş̧i Internelor and Others.

${ }^{11}$ For a critical analysis of the Court's approach, see generally C. Kilpatrick, 'On the Rule of Law and Economic Emergency: The Degradation of Basic Legal Values in Europe's Bailouts', 35(2) Oxford Journal of Legal Studies (2015) p. 325; A. Poulou, 'Financial Assistance Conditionality and Human Rights Protection: What is the Role of the European Charter of Fundamental Rights', 54(4) Common Market Law Review (2017) p. 991. 
sector for the period 2014-2018. The law was adopted after the Constitutional Court had struck down partially, ${ }^{12}$ or fully, ${ }^{13}$ pay cuts adopted in 2012, 2013, and early 2014. Before arriving at the Court of Justice, the new law had also been the subject of (this time ex ante) constitutional review: the Constitutional Court accepted salary cuts for the period 2014-2015, but struck down measures adopted for the following three years. ${ }^{14}$

In the domestic proceedings, the trade union brought an action for annulment of the administrative acts adopted under the law, temporarily reducing the judges' remuneration. The salary cuts had been abolished in the meantime, but no repayment or restitution had been made for the two years during which the measure was in force. In support of its action, the trade union claimed before the domestic court that the measures breached the principle of judicial independence set out in Article 203 of the Constitution and enshrined in both Article 19(1) TEU and Article 47 of the Charter. Despite the fact that the case law of the Court of Justice did not inspire optimism about its willingness to review austerity measures in the light of EU law and the Charter, the trade union nonetheless framed its case in EU law terms, probably because the Constitutional Court had considered the law constitutional for the period 2014-2015. The Supreme Administrative Court then asked the Court of Justice whether the temporary reductions infringed the principle of judicial independence enshrined in Article 19(1) TEU, Article 47 of the Charter and the case law of the Court of Justice. ${ }^{15}$ The key questions seemed, therefore, to concern the jurisdiction of the Court of Justice over national austerity measures adopted in the context of supranational conditionality, and the applicability of the Charter to such austerity measures.

In this sense, interest in the Portuguese case was growing; the Court of Justice had changed its position in Florescu ${ }^{16}$ on whether Memoranda of Understanding qualified as acts of EU institutions - for the purpose of preliminary rulings under Article 267 $\mathrm{TFEU}^{17}$ - and on whether national implementing measures fell within the scope of Union law, making the Charter applicable. In Florescu, which was incidentally also related to the remuneration of judges (pension rights, in that instance), the Court found, first, that the Memorandum of Understanding concluded between the EU

\footnotetext{
${ }^{12}$ See Portuguese Constitutional Court, 5 July 2012, Decision 353/2012

${ }^{13}$ See Portuguese Constitutional Court, 5 April 2013, Decision 187/2013; and Portuguese Constitutional Court, 30 May 2014, Decision 413/2014.

${ }^{14}$ See Portuguese Constitutional Court, 14 August 2014, Decision 575/2014.

${ }^{15}$ Although the court did not specify the cases to which it was referring, it does however seem that it was referring to general principles of EU law, see paras 14-15.

${ }^{16}$ ECJ 13 June 2017, Case C-258/14, Florescu.

${ }^{17}$ Under Art. 267 TFEU, the Court has jurisdiction to 'give preliminary rulings concerning... (b) the validity and interpretation of acts of the institutions, bodies, offices or agencies of the Union' (emphasis added).
} 
and Romania, in the context of financial assistance for Member States not part of the Eurozone ${ }^{18}$ 'constitute[d] an act of an EU institution' and could thus be interpreted by the Court in a preliminary ruling reference; ${ }^{19}$ second, that the national measure at stake constituted an implementation of EU law and thus made the Charter of Fundamental Rights applicable, ${ }^{20}$ since it had been adopted following a Memorandum of Understanding and a Council decision containing objectives that were 'sufficiently detailed and precise' and which permitted the inference that their implementation required pay cuts. ${ }^{21}$ In this respect, the fact that the Member State had 'broad discretion ${ }^{, 22}$ in adopting the impugned measure was no obstacle to the applicability of the Charter. ${ }^{23}$ The judgment has been praised for correcting the 'early crisis hypothesis, according to which the national systems were the main locus for designing and combating austerity and conditionality. ${ }^{24}$ It made it clear that a Memorandum of Understanding for balance-of-payments assistance is an act of EU institutions which could be referred to the Court of Justice under Article 267 TFEU for interpretation. It remained to be seen, however, whether the reasoning could be extended to a Memorandum of Understanding concluded under the EFSM - as was the case in Portugal - and possibly also under the European Financial Stability Facility (EFSF) and the European Stability Mechanism (ESM). ${ }^{25}$

It is from this perspective that the Advocate General addressed the reference in the Portuguese judges' case. Building on the opinion delivered by his colleague Yves Bot in Florescu, which was later followed by the Court, Advocate General Øe claimed that the Charter was applicable to the case, as the Portuguese measures in question (specifically Article 2 of Law 75/2014) constituted an implementation of EU law. ${ }^{26}$ He then proceeded to assess the compatibility of those measures with

${ }^{18}$ See Council Regulation 332/2002 establishing a facility providing medium-term financial assistance for Member States' balances of payment.

${ }^{19}$ Florescu, supra n. 16, paras. 35-36.

${ }^{20}$ Ibid., para. 48.

${ }^{21}$ Ibid., para. 48. Moreover, both the wording and the intent of the legislature in adopting the measures implementing the Memorandum were clear: see also the Opinion of AG Bot, paras. 65 and 66.

${ }^{22}$ Florescu, supra n. 16, para. 48.

${ }^{23}$ The Court did in any case conclude that there had been no breach of Art. 17 of the Charter in the case: see para 60 .

${ }^{24}$ See M. Markakis and P. Dermine, 'Bailouts, the legal status of Memoranda of Understanding, and the scope of application of the EU Charter: Florescu', 55 Common Market Law Review (2018) p. 662 .

${ }^{25}$ For the latter two instruments, however, a potentially important difference is that they are formally situated outside the EU legal framework. This contribution does not aim to tackle the question of whether ESM and EFSF Memoranda of Understanding qualify as acts of EU institutions.

${ }^{26}$ As suggested by Bot in Florescu, the AG reaches this conclusion on the basis of the wording and the terms of the measures of EU law: see paras. 48 and 52 of the Opinion. 
Article 47 of the Charter, which contains the fundamental right to a hearing before an independent tribunal.

The austerity aspect of the case was, however, entirely downplayed by the Court of Justice. While it may have seemed that the moment had come for the Court 'to come clean on the legal nature of Memorandums of Understanding ${ }^{27}$ and the applicability of the Charter to Member States carrying out austerity measures in that context, the Court avoided the issue entirely. ${ }^{28}$ It chose instead to approach the preliminary reference from Portugal from a very different perspective, seizing the opportunity to develop its views on the European judiciary and judicial independence on the basis of Article 19 TEU.

\section{The DeCision of THE CourT}

The Court transformed what at first seemed to be an austerity case into a 'rule of law' one, with two main objectives in mind: first, to gain a say in the Polish discussion; second, and more generally, to make it clear that the organisation of national judiciaries is not a purely domestic matter. ${ }^{29}$ In order to do so, however, it had to face several challenges, which required a significant amount of judicial creativity. In the first place, the Court wanted to declare the case admissible and assume jurisdiction, even though it had avoided doing so in previous austerity cases. Second, in assuming jurisdiction, it wanted to avoid a detailed discussion on the scope of the Charter of Fundamental Rights. This was crucial because, in Poland, the most controversial measures on the judiciary do not seem to fall within the scope of EU law as traditionally understood. ${ }^{30}$ Moreover, the Court's interpretation of Article 51(1) Charter is still controversial, especially when it makes the Court seem to encroach upon retained competences or essential state functions, or where it enters into competition with constitutional courts. ${ }^{31}$ Third and finally, if it wanted to avoid using the Charter, the Court had to find an alternative linchpin in the Treaties and a new source for the principle of judicial independence.

\section{Preliminary questions: admissibility and jurisdiction}

In its ruling the Court quickly dismissed the arguments raised by the Portuguese government and the Commission on the procedural admissibility of the reference,

\footnotetext{
${ }^{27}$ As asked by Markakis and Dermine, supra n. 24, p. 661.

${ }^{28}$ For a critical analysis of the Court's approach in this respect, see F Pereira Coutinho, 'Associação Sindical dos Juízes Portugueses: judicial independence and austerity measures at the Court of Justice', 2 Quaderni costituzionali (2018) p. 510-511.

${ }^{29}$ On this second aspect, see the final section of this paper.

${ }^{30}$ See infra.

${ }^{31}$ See e.g. J. Komarek, 'National constitutional courts in the European constitutional democracy', 12(3) International Journal of Constitutional Law (2014) p. 525.
} 
arguing that the order for reference '[contained] sufficient information' on the reasons for asking for an interpretation of Articles $19 \mathrm{TEU}$ and $47 \mathrm{Charter},{ }^{32}$ and that the abolishment, in 2016, of the salary-reduction measures in question did not devoid the proceeding of purpose, since there had been no restitution of the salaries for the two years in which the measure was applicable. ${ }^{33}$

On jurisdiction, and thus on the question of whether the national law in question fell within the scope of Union law, the Court's assessment was more complex and central to the decision. The Portuguese government and the Commission, well aware of the previous case law of Luxembourg on (Portuguese) austerity measures, ${ }^{34}$ tried to deny jurisdiction by repeating the mantra that the referring court had not sufficiently explained why the relevant legislation should be considered as implementing EU law in the sense of Article 51 of the Charter. ${ }^{35}$ The Supreme Administrative Court, on the other hand, had tried its best to bring the case within the scope of EU law in its reference using several different arguments. First, it emphasised that the Tribunal de Contas monitors in particular the receipt of EU own resources and the use of financial resources from the European Union and may act in that field in cooperation with the relevant EU bodies. ${ }^{36}$ The activities of the Tribunal de Contas would therefore come under the jurisdiction of the Court of Justice insofar as the Portuguese court could decide on questions of interpretation and application of Union law. Second, the Supreme Administrative Court claimed that the measures at issue, i.e. the salary reductions, formed part of the context of the correction of the excessive deficit in Portugal regulated and supervised by the institutions of the European Union - followed by financial assistance - granted and regulated by EU legal measures - and thus that it would be difficult to deny that those measures had been adopted in the framework of EU law or, at least, were 'European in origin' ${ }^{37}$ Finally, it claimed that EU law imposes requirements concerning the independence of the judiciary on national courts, as they form part of the European judiciary under Article 19(1) TEU, second sentence, and Article 47 Charter demands judicial independence.

Contrary to what might have been expected after the decision in Florescu and the Opinion of the Advocate General, the Court of Justice avoided any kind of discussion on whether austerity measures fell within the scope of EU law. In assuming jurisdiction, it concentrated on the position of national courts within

${ }^{32}$ ASJP, supra n. 1, para. 21.

${ }^{33}$ ASJP, supra n. 1, para. 25.

${ }^{34}$ It should be noted that that hearing took place before the decision in Florescu, i.e. before the change of orientation of the Court on the matter.

${ }^{35}$ The arguments are summarised in the Opinion of the AG, para. 37.

${ }^{36}$ See in particular Art. 5(1)(h) of Law 98/97 on the organisation and procedure of the Court of Auditors and Art. 214 of the Portuguese Constitution.

${ }^{37}$ ASJP, supra n. 1, para. 14. For a list of relevant EU measures, see para. 4 of the AG Opinion. 
the European judiciary and on the Tribunal de Contas as one of those national courts. This is evident from the very first paragraphs of the 'substance' part of the ruling. The Court begins by reformulating the question raised by the Portuguese court, concentrating exclusively on Article 19 TEU and brushing aside the discussion on the Charter's applicability. ${ }^{38}$ It then proceeds to construct a new 'sphere' of EU law.

\section{A new sphere of EU law}

The Court begins this construction by emphasising that the material scope of Article 19 TEU is different from the material scope of the Charter. This is a rather surprising starting point; one would expect the reasoning to work the other way around, with the Charter following the application of EU law, as explained by the Court since Akerberg Fransson: 'Since the fundamental rights guaranteed by the Charter must therefore be complied with where national legislation falls within the scope of European Union law, situations cannot exist which are covered in that way by European Union law without those fundamental rights being applicable. ${ }^{39}$ This has usually been explained as meaning that the scope of the Charter follows the scope of EU law: when a situation comes in the scope of EU law ('is governed by EU law'), then the Charter applies. ${ }^{40}$ In other words, the Charter is the 'shadow' of substantive EU rules. ${ }^{41}$ The crucial question thus was always to decide whether a situation would come in the scope of EU law ('situations governed by EU law', or 'where EU law is applicable', which is always the case when 'Member States are implementing EU law').

Here, the Court introduces a new sphere by stating that the material scope of Article 19(1) TEU is broader than that of Article 51(1) Charter. ${ }^{42}$ There are apparently cases that fall under the jurisdiction of the Court of Justice since they belong to 'the fields covered by EU law', which are not at the same time covered by the notion 'the Member States implementing EU law'. ${ }^{43}$ Therefore, what the Court seems to be saying here is that it does not need to ascertain whether, in

${ }^{38}$ ASJP, supra n. 1, para. 28.

${ }^{39}$ ECJ 23 February 2013, Case C-617/10, Åkerberg Fransson, para. 21.

${ }^{40}$ Confirmed recently for example in ECJ 16 May 2017, Case C-682/15, Berlioz, para. 49: 'the Court has consistently held that the fundamental rights guaranteed in the legal order of the European Union are applicable in all situations governed by EU law and that the applicability of EU law entails applicability of the fundamental rights guaranteed by the Charter'.

${ }^{41}$ K. Lenaerts and A. Gutiérrez-Fons, 'The Place of the Charter in the EU Constitutional Edifice', in S. Peers et al. (eds.), The EU Charter of Fundamental Rights. A Commentary (Hart 2013).

${ }^{42}$ ASJP, supra n. 1, para. 29.

${ }^{43}$ The AG had proposed a similar interpretation of Art. 19 TEU as the Court, rejecting the positions of the Portuguese Government and the Commission claiming that the Court's jurisdiction on Art. 19 TEU was limited in the same way as it was for Art. 47 Charter. 
adopting the cuts, Portugal is or is not 'implementing EU law', since the Tribunal de Contas is a court or tribunal that comes in the judicial system of the EU 'in the fields covered by EU law' under Article 19(1) TEU. The mere fact of being a court or tribunal with the competence to potentially decide on the interpretation or application of Union law is sufficient to come within the material scope of Article 19 TEU. ${ }^{44}$ Thus, there is a sphere of EU law, namely the 'fields covered by Union law', in which EU law applies - in the sense that Member States must ensure effective judicial protection under Article 19 TEU - but the Charter does not. ${ }^{45}$ This is puzzling in the light of established case law in which the Charter is co-extensive with EU law or, in other words, where the scope of the Charter overlaps with that of EU law. ${ }^{46}$

This new sphere of EU law seems to be a 'functional' rather than a traditional 'substantive' one: the key factor for falling under the jurisdiction of the Court is not whether the circumstances of the case touch upon matters regulated by Union law, but the function of national courts as part of the European judiciary. A link with a 'substantive rule of EU law' is thus still required, but it can be more indirect; it is sufficient for the relevant court to 'potentially' apply or interpret EU law. The conclusion of the Court is even more striking since, as might have been expected after Florescu, the Portuguese measures in the annotated case could be brought within the scope of EU law and the case could have been decided on the basis of Article 47 of the Charter.

Again, the key to understanding why the Court chose to take a difficult detour via Article 19 TEU rather than the direct route via the Charter lies in the Polish rule of law crisis. It may be recalled that in the infringement action against the Polish 'Law on Ordinary Courts', the Commission raised two arguments: an

${ }^{44} A S J P$, supra n. 1, para. 40 .
${ }^{45}$ For a different conclusion, see B. Pirker, 'Mapping the Scope of Application of EU Fundamental Rights: A Typology', 3 European Papers (2018) p. 156, arguing that 'EU fundamental rights also apply in the particular situation defined in Associacao Sindical dos Juizes Portugueses'. The author reaches the conclusion on the basis of para. 35 of the judgment, in which the Court, as will be discussed below, describes effective judicial protection as a 'general principle of EU law', deriving from common constitutional traditions and the ECHR and confirmed by Art. 47 of the Charter. It is not entirely clear whether the author believes that fundamental rights of the Charter are applicable or 'only' fundamental rights as general principles of EU law (see Art. 6 TEU). Irrespective of this, the reasoning is not convincing as the Court does not assess Portuguese measures on the basis of fundamental rights, but only on the basis of Art. 19 TEU, which is considered the source of the principle of judicial independence in EU law.

${ }^{46}$ Of course, the Charter is also part of 'EU law'. What is meant here is the application of EU law triggering the application of the Charter, often referred to as 'substantive EU rules' or 'triggering rules'. On the concept of 'triggering rule' for the application of the Charter, see D. Sarmiento, 'Who's afraid of the Charter? The Court of Justice, National Courts and the new Framework of Fundamental Rights Protection in Europe', 50(5) Common Market Law Review (2013) p. 1267. 
infringement of EU anti-discrimination provisions related to the different retirement ages for male and female judges; and a breach of the principle of judicial independence due to the fact that the Ministry of Justice acquired the discretionary power to extend the mandate of judges who have reached the new retirement age. ${ }^{47}$ The second issue cannot, however, be brought within the scope of EU law as traditionally understood, and that aspect of the case arguably therefore cannot be decided on the basis of the Charter. ${ }^{48}$ The Court nonetheless aimed to find a way to decide on the infringement action, and found support in Article 19 TEU, which in the view of the Court extends its jurisdiction over courts and tribunals that may potentially apply or interpret EU law. At the same time, the Court was fully aware that extending the scope of the Charter to coincide with the new interpretation of Article 19 TEU would open it to criticism as it would be taking the Charter even beyond Akerberg Fransson, to cases which are potentially within the reach of EU law. It realised that that would not be an acceptable course of action and decided not to consider Article $19 \mathrm{TEU}$ as a triggering rule for the application of the Charter.

\section{The principle of effective judicial protection}

Following its creative interpretation of the scope of application of Article 19 TEU, the Court proceeded with an equally creative construction of its content. First the Court reflected on the concept of effective judicial protection in Union law. The Court began by making a general reference to Article 2 TEU and in particular to the rule of law as a founding value of the Union, ${ }^{49}$ saying that Article 19 gives 'concrete expression' to the value of the rule of law, and does so by entrusting the key function of judicial review not only to the Court of Justice, but also to national courts and tribunals. ${ }^{50}$ In other words, Article 19 makes all national courts or tribunals, or more precisely all courts and tribunals that may potentially be called to interpret or apply Union law, part of the European judiciary and thus 'European courts'. As those bodies form part of the European judiciary, the Member States are obliged, inter alia under the principle of sincere cooperation, to ensure the application of EU law and effective judicial protection of individuals in the fields covered by EU law.

\footnotetext{
${ }^{47}$ European Commission, Rule of Law: European Commission acts to defend judicial independence in Poland, Press release of 20 December 2017, IP/17/5367; see also Case C-192/18, Commission $\mathrm{v}$ Poland, pending.

${ }^{48}$ The first issue is, on the other hand, covered by EU law, more specifically the Equal Treatment Directive.

${ }^{49}$ ASJP, supra n. 1, para. 30.

${ }^{50}$ ASJP, supra n. 1, para. 31.
} 
The Court then gave further substance to the principle of effective judicial protection by linking it to the Member States' common constitutional traditions, Articles 6 and 13 of the ECHR, and Article 47 of the Charter - which is therefore brought back into the equation, if only for guidance and support for the interpretation of Article 19 TEU. ${ }^{51}$ By connecting the principle of effective judicial protection to the value of the rule of law, on the one hand, and to fundamental rights' provisions on the other, the Court gave substance to the concept. On these bases, the Court concludes this part of its construction by affirming that Member States must ensure that bodies that come within the EU judicial system as courts or tribunals 'meet the requirements of effective judicial protection' ${ }^{52}$

\section{Judicial independence as an obligation deriving from Article 19 TEU}

One of these requirements, the Court continued, is that courts or tribunals must be 'independent'. There is, however, no textual reference in Article 19 to support this interpretation, and the Court needed again to find support in other Treaty provisions. In this respect, the first building block was the case law under Article 267 TFEU. The Court has in fact given an EU meaning of 'court or tribunal' for the sake of of Article 267 TFEU in order to decide whether a body can send questions for preliminary ruling. One of the conditions is that the body in question must be 'independent'. As a first building block, this reference is not entirely convincing, and might even have paradoxical effects. ${ }^{53}$ In this line of case law, independence is not a requirement imposed by EU law, but rather a condition that must be met for the body to the considered a court or tribunal in the first place. If a body is not independent, it does not qualify as a court or tribunal in the sense of Article 267 TFEU, meaning that it cannot send a preliminary reference, but there are no further negative consequences for the Member State in question. In the Portuguese case however, (the protection of) judicial independence was suddenly transformed into a general obligation imposed on the Member States, which applies to all courts and tribunals that may potentially act as European judges. While the Court later supported this finding by arguing that the independence of courts and tribunals was 'essential to the proper working' of the European judicial cooperation system, the way in which judicial independence was first introduced in the case was abrupt and not entirely logical. ${ }^{54}$

${ }^{51}$ Ibid., para. 35.

${ }^{52}$ Ibid., para. 37.

${ }^{53}$ To be discussed infra.

${ }^{54}$ ASJP, supra n. 1, para. 38: it might seem that in this paragraph the court is explaining the requirements of effective judicial protection, but actually those factors are related to something quite different, namely the factors to be considered for a body to be qualified as a court or tribunal. 
The Court then referred, as its second building block, to Article 47 of the Charter, which confirms, according to Luxembourg, that maintaining the independence of a court or tribunal is essential for judicial protection to be effective. ${ }^{55}$ For the second time, therefore, Article 47 of the Charter - here when it refers to 'access to an "independent" tribunal' - is used in the ruling to support the interpretation of Article 19 TEU, despite the fact that the issue of the applicability of the Charter had been brushed aside in the opening paragraphs of the decision. ${ }^{56}$

Another, more implicit, building block was the principle of mutual trust. It was only briefly mentioned in the judgment, ${ }^{57}$ but it seems to have underpinned the reasoning: only independent courts can be trusted - by European citizens, the Court of Justice, and other national courts - with the loyal application of EU law. This was confirmed by the President of the Court of Justice who reminded us in a recent speech in Warsaw of the importance of mutual trust and judicial independence for EU judicial dialogue, discussing the 'mutually-reinforcing' relationship between these two concepts, in particular in the context of the European Arrest Warrant. ${ }^{58}$ In order for courts to 'trust each other', President Lenaerts argued, 'they must independent'. Protecting judicial independence is thus key to fostering mutual trust between national courts, and between national courts and the Court of Justice.

Finding support in these other provisions and principles of Union law, the Court concluded that Article 19 TEU includes an obligation to uphold judicial independence. In other words, judicial independence has now acquired a new role within the EU constitutional order as a primary law obligation. It now appears in the EU constitutional framework under many guises: as a value under Articles 2 and 49 TEU (implicit in the rule of law), promoted in the enlargement policy under the Copenhagen criteria ${ }^{59}$ and safeguarded by the EU institutions after accession; $^{60}$ as a fundamental right under Article 47 of the Charter; as a

${ }^{55}$ ASJP, supra n. 1, para. 41.

${ }^{56}$ But see para. 46, where the Court - all of a sudden - stated that the measures had been adopted in the context of an EU programme and because of 'mandatory requirements', thus suggesting that the circumstances of the case brought it within the 'normal' scope of EU law, thus triggering application of the Charter.

${ }^{57}$ ASJP, supra n. 1, para. 30.

${ }^{58} \mathrm{~K}$. Lenaerts, 'The Court of Justice and national courts: a dialogue based on mutual trust and judicial independence', Speech at the Supreme Administrative Court of the Republic of Poland, Warsaw, 19 March 2018, available at <www.nsa.gov.pl/download.php?id=753\&mod=m/11/ pliki_edit.php>, visited 31 July 2018.

${ }^{59}$ For a critical assessment of the EU's promotion of judicial independence during the Eastern Enlargement, see M. Bobek and D. Kosař, 'Global Solutions, Local Damages: A Critical Study in Judicial Councils in Central and Eastern Europe', 15(7) German Law Journal (2014) p. 171.

${ }^{60}$ It features as a key rule of law principle in the Commission Rule of Law Framework, for example: see European Commission, A new EU Framework to strengthen the Rule of Law, Brussels, 
requirement for courts or tribunals to be able to make references under Article 267 TFEU; and now as a primary law obligation enforceable by the Court of Justice, deriving from Article 19 TEU, that binds Member States 'in the fields covered' by Union law.

\section{The assessment of Portuguese austerity measures}

In the last part of the ruling, the Court set out the criteria for assessing the independence of a court or tribunal, and then applied them to the concrete measures taken by the Portuguese State. As for the criteria, the Court referred to two cases Wilson $^{61}$ and Panicello ${ }^{62}$ - in which the extensive case law on the independence of 'courts or tribunals' was summarised. ${ }^{63}$ The Court added specifically that 'a level of remuneration commensurate with the importance of the functions' judges carry out was 'a guarantee essential to judicial independence.' ${ }^{64}$

The application of the standards to the concrete case was brief and uncontroversial. The Court concluded that the salary reductions implemented by Portuguese authorities had not impaired the independence of the judiciary: the reduction in question was limited, ${ }^{65}$ was applied to all office holders and publicsector employees, ${ }^{66}$ and was temporary in nature. ${ }^{67}$ Hence, the Court held that Portugal had not breached its obligations under Article 19(1) TEU when adopting law 75/2014. The short and straightforward analysis of the national measures at stake shows once more that the Court had been less interested in the specific outcome of the case at hand than in making a general point about the European judiciary - and in creating an opportunity to assess the controversial judicial reforms in Poland.

19 March 2014, COM(2014) 158final/2, and in particular Annex I; and has been mentioned several times in the Commission Recommendations under it, as well as in the Reasoned Proposal on the activation of Article 7 against Poland.: see e.g. European Commission, Recommendation regarding the Rule of Law in Poland, Brussels, 27 July 2016, Doc. C(2016) 5703 final; and European Commission, Reasoned Proposal in accordance with Article 7(1) of the Treaty on European Union regarding the Rule of Law in Poland - Proposal for a Council Decision on the determination of a clear risk of a serious breach by the Republic of Poland of the rule of law, Brussels, 20 December 2017, Doc $\operatorname{COM}(2017) 835$ final.

${ }^{61}$ ECJ 19 September 2006, Case C-506/04, Wilson.

${ }^{62}$ ECJ 16 February 2017, Case C-503/15, Margarit Panicello.

${ }^{63}$ See ASJP, supra n. 1, para. 44: 'the concept of independence presupposes, in particular, that the body concerned exercised its judicial functions wholly autonomously, without being subject to any hierarchical constraint or subordinate to any other body and without taking orders or instructions from any source whatsoever, and that it is thus protected against external interventions or pressure liable to impair the independent judgment of its members and to influence their decisions'

${ }^{64}$ Ibid., para. 45.

${ }^{65}$ Ibid., para. 47.

${ }^{66}$ Ibid., para. 48.

${ }^{67}$ Ibid., para. 50. 


\section{What the DeCision IS REALly about: Polish (and Hungarian?) JUdGeS}

The ruling of the Court of Justice in C-64/16 can best be understood by shifting the attention from Lisbon to Warsaw. The story of the deterioration of the rule of law in Poland is, unfortunately, well known. ${ }^{68}$ In particular, the adoption by the Polish Parliament in the last months of 2017 of a wholesale reform of the Polish judiciary has provoked outrage across Europe and reaction at the EU level; ${ }^{69}$ the Commission has initiated the procedure under Article 7(1) TEU, issuing a Reasoned Proposal that signals its concerns for the situation of the rule of law in Poland, ${ }^{70}$ and begun an infringement action against the Law on Ordinary Courts.

With the decision in the Portuguese case, the Court has now sent a signal that it is willing to assess national measures that allegedly undermine the independence of the national judiciary as part of the EU judiciary on the basis of EU primary law, irrespective of whether the Charter applies. This implies that Article 19 TEU applies to situations that are not related to any substantive area of EU law as long as the national courts and tribunals in question may be called to decide on the interpretation or application of Union law. This is important, as several other aspects of the Polish legislative changes do not otherwise come in the scope of EU law as traditionally understood, such as the power of the Minister of Justice to decide on the extension of the mandate of judges who have reached the new retirement age; his power to dismiss and appoint court presidents; ${ }^{71}$ and the reform of the Supreme Court and the National Council of the Judiciary.

The decision of the Court of Justice is not only relevant for the pending infringement case on the Law on Ordinary Courts, as noted in the previous section, but also an invitation to the Commission to initiate other infringement actions directly on the basis of Article 19 TEU. The Commission followed

\footnotetext{
${ }^{68}$ For an overview: W. Sadurski, 'How Democracy Dies (in Poland): A Case Study of AntiConstitutional Populist Backsliding', Legal Studies Research Paper No. 18/01 (2018); L. Pech and K.L. Scheppele, 'Illiberalism Within: Rule of Law Backsliding in the EU', 19 Cambridge Yearbook of Legal Studies (2017) p. 3.

${ }^{69}$ For a detailed discussion of the amendments, see European Commission, Reasoned Proposal in accordance with Article 7(1) TEU of the Treaty on European Union regarding the Rule of Law in Poland - Proposal for a Council Decision on the determination of a clear risk of a serious breach by the Republic of Poland of the rule of law, Brussels, 20 December 2017, Doc. COM (2017) 835 final, and Venice Commission, Opinion 904/2017 on the Draft Act Amending the Act on the National Council of the Judiciary, on the Draft Act Amending the Act on the Supreme Court, Proposed by the President of Poland, and on the Act on the Organisation of Ordinary Courts, Strasbourg, 11 December 2017, Doc. CDL-AD(2017)031

${ }^{70}$ Reasoned Proposal, supra n. 69.

${ }^{71}$ See European Commission, supra n. 69 and Venice Commission, supra n. 69. The Polish Parliament has, however, in the meantime approved some further amendments to the system: the decision of the Minister now requires confirmation from the National Council of the Judiciary.
} 
through in the first week of July 2018, launching a new action against Poland regarding the changes to the law on the Supreme Court. ${ }^{72}$ Surprisingly, however, the Commission did not restrict itself to invoking Article 19(1) TEU, but rather Article 19 'read in connection with Article 47 of the Charter', raising new questions on the scope of application of the latter document. If our reading of the Portuguese decision is correct, however, the Court would only be able to assess the alleged breach of judicial independence on the basis of Article 19 TEU, and not Article 47 Charter. In terms of the concrete assessment, this might not make a difference, as the Court seems willing to align the substantive content of the two provisions. ${ }^{73}$ In other words, assessing national measures on the basis of fundamental rights (Article 47 of the Charter) or a rule of law principle (Article 19 TEU) should produce at least similar, if not identical, results.

Questions on the compatibility of the Polish measures with Article 19 TEU and EU law could also come to the Court of Justice by means of preliminary references. In this respect, the Court's ruling could, however, create some tension. If Luxembourg were to find that the Law on the Ordinary Courts infringed the principle of independence of Polish courts enshrined in Article 19(1) TEU, would this imply that those courts could no longer make references for preliminary rulings under Article 267 TFEU since they failed to meet one of the criteria for qualification as a 'court or tribunal'? Surely this is not the result the Court of Justice would want to achieve, but the reasoning developed in the Portuguese case, in particular the references to Article 267 TFEU as one of the sources of the judicial independence requirement, could lead to this paradoxical conclusion. A further clarification would be welcome in the impending decision on the enforcement action against Poland. Indeed, despite the challenges they are facing, Polish courts may still be playing on the side of the Court of Justice and could potentially send further references challenging national measures on the basis of Article 19 TEU. Similar actions and procedures could also be started in Hungary, where the independence of national courts, including the Constitutional Court, has been undermined by the constitutional and institutional reforms undertaken under Viktor Orbán's governments. ${ }^{74}$

\footnotetext{
${ }^{72}$ European Commission, Press Release: Rule of Law: Commission launches infringement procedure to protect the independence of the Polish Supreme Court, Brussels, 2 July 2018, Doc IP/ $18 / 4341$.

${ }^{73}$ See ASJP, supra n. 1, para. 41, where the Court refers back to Art. 47 of the Charter of Fundamental Rights in order to give substance to the principle of judicial independence.

${ }^{74}$ See e.g. Venice Commission, Opinion 663/2012 on ACT CLXII of 2011 on the legal status and remuneration of judges and Act CLXI of 2011 on the organization and administration of courts in Hungary, Strasbourg, 19 March 2012 (CDL-AD(2012)001). On the relationship between the two provisions, see in more detail M. Kraiewski, 'Associação Sindical dos Juízes Portugueses: The Court of Justice and Athena's Dilemma', 3 European Papers (2018) p. 395.
} 
The standards for the assessment of 'judicial independence' in cases like Hungary and Poland pose an additional and significant challenge. In the Portuguese judges' decision, the case law on Article 267 TFEU served as an important source for the principle of 'judicial independence'. But that case law is not entirely coherent; the Court has not, generally speaking, been strict in interpreting the requirements created under Article 267 TFEU, including that of 'independence'. On the basis of such decisions as Köllensperger and Atzwanger ${ }^{75}$ and Gabalfrisa, ${ }^{76}$ it has been suggested that the Court has applied 'a lax criterion of judicial independence. ${ }^{77}$ The core concern of the Court has not been, as is the case for the European Court of Human Rights when it decides on the independence of national courts under Article $6 \mathrm{ECHR}$, to protect the right of individuals to an independent tribunal, but rather, perhaps even on the contrary, to broaden access to the preliminary reference procedure. This is done in order to guarantee, to the greatest extent possible, uniform application of Union rights and their effective protection. ${ }^{78}$ For example, even bodies not formally recognised as courts or tribunals under national law, and only loosely independent from the parties including the administration, have been brought within the scope of Article 267 TFEU, especially when they take final decisions affecting rights deriving from Union law. ${ }^{79}$

In Wilson the Court developed the concept of judicial independence to some extent, distinguishing between an internal and an external dimension. The first can be described as 'impartiality' towards the parties; ${ }^{80}$ the latter, more significantly for the discussion developed in this contribution, protects the judiciary from undue political

\footnotetext{
${ }^{75}$ ECJ 4 February 1999, C-103/97, Köllensperger and Atzwanger. In this case, the Court of Justice concluded that the Tyrol's Procurement Office was an independent body despite the fact that the law governing its composition and function provided rather vague guarantees on the member's tenure and dismissal.

${ }^{76}$ ECJ 21 March 2000, C-110/98, Gabalfrisa. The independence of the Spanish tribunals reviewing decisions of tax authorities was considered sufficient regardless of the fact that Minister for Economic Affairs could directly appoint or dismiss the members of the tribunals, in view of the fact that there was a separation of functions between the ministers and the tribunals.

${ }^{77}$ T. Tridimas, 'Knocking's on Heaven's door: Fragmentation, Efficiency and Defiance in The Preliminary Reference Procedure', 40 Common Market Law Review (2003) p. 30. See also M. Broberg, 'Preliminary References by Public Administrative Bodies', 15 European Public Law (2009) p. 221 For a critique of the Court's case law, inspired by Art. 6 ECHR and the Strasbourg's jurisprudence: see AG Colomer's Opinion in ECJ 29 November 2001, C-17/00, François De Coster v Collège des bourgmestre et échevins de Watermael-Boitsfort.

${ }^{78}$ See also Tridimas, supra n. 77.

${ }^{79}$ For two examples, see ECJ 6 October 1981, C-246/80, Broeckmeulen, in which 'a certain degree of governmental supervision' was no obstacle for a preliminary reference; and ECJ 17 July 2014, Joined Cases C-58/13 and C-59/13, Torresi.

${ }^{80}$ See Wilson, supra n. 61, para 52: 'The second aspect, which is internal, is linked to impartiality' (emphasis added).
} 
and administrative influences and pressure. External independence must be guaranteed both in concreto - no undue influence in a specific case - and more structurally, for example by establishing guarantees against removal from office or on judicial careers. However, in Wilson the Court was assessing whether the Ordre des avocats du barreau de Luxembourg fulfilled the conditions of Article 9 of Directive 98/5 on free movement of lawyers, requiring Member States to put in place remedies 'before a court or tribunal' against negative registration decisions. In this sense, it is understandable that the Court took a firmer stance on the independence of the body concerned and concluded that it did not fulfil the conditions: its aim in the decision was to guarantee that individuals had access to an independent body, not to broaden access to the preliminary reference procedure.

The criteria developed in the case law thus far have served in contexts that are fundamentally different from a systemic threat to the rule of law and the independence of the judiciary, as is the case in both Poland and also in Hungary. The Court has used the criteria to determine judicial independence in a quite relaxed manner, since it has the aim to bring as many bodies interpreting and applying EU law as possible within the scope of the preliminary reference procedure. Moreover, the Court has used the criteria to determine the independence of specific, concrete bodies that have sent a reference, and not to assess whether all courts of a Member State are independent in spite of comprehensive institutional changes; or, reversing the perspective, whether a specific piece of legislation affects the independence of the judiciary as a whole. Ergo, the criteria developed thus far do not seem sufficiently strict to arrive at a decision that a Member State has infringed its (general) obligation to ensure judicial independence under Article 19 TEU. ${ }^{81}$ The Court could, however, find support for its analysis by looking to the Article 6 ECHR jurisprudence of the European Court of Human Rights and perhaps also to the non-judicial analyses of judicial independence conducted during the accession process, in rule of law oversight by the Commission, and by the Venice Commission.

Having affirmed that judicial independence is an EU primary law obligation, Luxembourg now has the possibility to move to the centre of the stage in the Polish crisis. The Court does not wish to remain marginalised in one of the most relevant EU constitutional law debates, but until now it has had very limited opportunity to express its views on the rule of law situation in Poland. ${ }^{82}$ With the

${ }^{81}$ See again the decision in ECJ 21 March 2000, C-110/98, Gabalfrisa in which, despite the fact that the Minister could directly appoint or dismiss the members of the tribunals, the Court still held the tribunal to be independent.

${ }^{82}$ For an implicit message, see ECJ 20 November 2017, Case C-441/17 R, Commission v Poland, para. 102: in allowing, for the first time in history, the imposition of pecuniary sanctions in case of non-compliance with interim measures, the Court made reference to the principle of the rule of law. Even in Hungary it could only intervene in infringement actions that were narrowly framed: see ECJ 
creative interpretation of Article 19 TEU described in this contribution, the Court has broadened its possibilities for intervention. The infringement action against the Law on the Ordinary Courts, which has Article 19 as one of its bases, will be one of the first opportunities for Luxembourg to express itself. The Court could also decide to rely on Article 19 TEU in the Celmer/LM case, the much-discussed preliminary reference originating from Ireland. ${ }^{83}$ The Irish High Court has asked the Court of Justice whether it should execute a European Arrest Warrant and surrender an individual to the Polish authorities in view of the systemic threats to the rule of law in that country that are, according to the Irish judge, incompatible with the right to a fair trial. ${ }^{84}$ The reference is clearly not framed in the same manner as the Portuguese case, but the Court might want to take the opportunity to send another signal to the Polish government that further attempts to undermine the independence of the judiciary would be subject to the scrutiny of Luxembourg. The Opinion of Advocate General Tanchev suggests otherwise, however. ${ }^{85}$

In light of the serious deterioration of EU values in Poland, it seems good for the EU to acquire new possibilities for intervention. The difficulties in operationalising Article 7 TEU are evident, even after its first formal activation in December 2017: the Council has not yet scheduled a formal vote on the Commission proposal and reaching the required four-fifths majority seems to be a cumbersome process. Yet, just how far can and should the Court really go? Several scholars have in recent years suggested that the Court of Justice should acquire new powers to review Member State compliance with EU values and de facto replace the political mechanisms created by the Treaties. ${ }^{86}$

Yet, there are many challenges ahead for a Court that wishes to intervene. In the first place, it should not be forgotten that the Treaty drafters assigned limited competences to the Court under Article 7 TEU. The Court can only review respect for the procedural requirements, but not the substantive determinations of the political institutions. ${ }^{87}$ More fundamentally, the legitimacy of the EU in

6 November 2012, Case C-286/12, Commission v Hungary; and ECJ 8 April 2014, Case C-288/12, Commission v Hungary.

${ }^{83} \mathrm{C}-216 / 18$ PPU, Minister for Justice and Equality $\mathrm{v} L M$, pending.

${ }^{84}$ More precisely, the Irish Court is asking whether the Aranyosi and Caldararu test (see ECJ 26 April 2016, Joined Cases C-404/15 and C-659/15 PPU) is applicable in the Polish context. This would require the Irish High Court to make an individual assessment of the specific situation of the individual. See High Court of Ireland, 23 March 2018, The Minister for Justice and Equality and Artur Celmer [2018] IEHC 153.

${ }^{85}$ See Opinion of AG Tanchev in ECJ 28 June 2018, Case C-216/18 PPU, LM.

${ }^{86} \mathrm{See}$ e.g. K.L. Scheppele, 'Enforcing the basic principles of EU law through systemic infringement actions', in C. Closa and D. Kochenov (eds), Reinforcing Rule of Law Oversight in the European Union (Cambridge University Press 2016).

${ }^{87}$ See Art. 269 TFEU. 
exercising rule of law and, more generally, values oversight has been contested. With stronger intervention in the rule of law crises, the Court might open itself up to the criticism that it is interfering with Member States' retained competences, with little or no legal basis in the Treaties. This is not to deny that intervention can be beneficial, but rather calls for caution in exercising the newlyacquired powers.

Moreover, the complexity of the assessment should now be evident. Even if one were to accept that the principle of judicial independence was inherent to Article 19 TEU, the standards by which independence is to be measured are currently unclear and should be more precisely developed in the future. The best framework for doing so is arguably provided by enforcement actions aimed at specific pieces of legislation such as the Law on Ordinary Courts and the Law on the Supreme Court. This would seem to be much more promising than preliminary references that question the independence of the entire judiciary or a specific court. It is also much more concrete than the systemic infringements proposed in the literature, and should be intended as a complement to, rather than a replacement of, existing political instruments including, first and foremost, Article 7 TEU. After all, while there is little guarantee that the Court will be more efficient than political bodies in safeguarding the rule of law against a State that does not respect it, a combination of legal and political solutions might increase the pressure on the political authorities of the Member State in question to comply with EU requirements.

\section{BOLSTERING THE EUROPEAN JUdicIARY}

In its ruling in the Portuguese case, the Court of Justice has clearly displayed an active, even political attitude. While the case initially seemed to be about judicial review of austerity measures and the applicability of the Charter in cases of national austerity measures implementing Memoranda of Understanding (under the EFSM), the Court transformed it into something radically different. The austerity questions themselves have gone unanswered: it remains to be seen, after Florescu, whether the Court will be inclined to take a broader stance on judicial review of austerity measures ${ }^{88}$ whether it will assume jurisdiction in more cases, and whether the Charter will be applicable in those cases.

The Court used the Portuguese reference as an opportunity to volunteer its involvement in the Polish rule of law crisis. In order to do so, the Court developed a complex and not entirely convincing construction composed of several building blocks found in the Treaties. First, it introduced a new sphere of EU law, positing

${ }^{88}$ Also suggested by the decision in ECJ 20 September 2016, Cases C-8/15 to C-10/95, Ledra. 
that Article 19 TEU imposes an obligation on the Member States to ensure that all courts and tribunals that may potentially be called on to apply and interpret EU law offer effective judicial protection. The reach of Article 19 TEU is more extensive than the Charter while at the same time not as broad as Article 2 TEU, which applies across the board even when there is no link whatsoever with EU law, although it can only be enforced by way of the Article 7 TEU procedure and does not come under the purview of the Court of Justice.

Secondly, the Court stated, relying on Article 267 TFEU and also on Article 47 of the Charter, that Article 19 TEU contains an obligation to ensure judicial independence. Article $19 \mathrm{TEU}$ is thus both the key to affirming the jurisdiction of the Court and the source of the principle of judicial independence. In both these respects, the ruling went well beyond the existing case law.

With its decision in C-64/16, the Court has bolstered its own role in the Polish debate and more generally when Member States adopt measures that allegedly undermine judicial independence, the Hungarian case being another case in point. In doing so, it offers an incentive to the Commission, and potentially to Polish and other Member State courts, to bring further actions before Luxembourg that could contribute to guaranteeing judicial independence. As argued above, it is a welcome development that the EU has acquired new possibilities for tackling the severe degradation of the rule of law in Poland and other countries, especially in view of the fact that political mechanisms have yet to achieve the expected results. Increased legal pressure might provide an incentive to speed up political procedures. Yet, as noted above, the legitimacy of the EU and the Court in exercising values oversight is contested. Having already stretched the scope of its oversight functions, the Court should perhaps be prudent in the concrete exercise of its newly-acquired powers. The good news is that the Court seems to be well aware of the sensitivity of the exercise: it intentionally leaves the Charter out of the equation so as to avoid critique - at least on that front.

The impact of the case will therefore mainly be felt in the context of the discussion on EU rule of law oversight in Hungary and Poland. But on a perhaps even broader note, the fact that the Court of Justice is breathing new life into Article 19 TEU is noteworthy. A few days after the ruling in C-64/16, the Court delivered another seminal decision in Achmea. There, it once again made several references to Article 19 and to the interpretation of it offered in the Portuguese case $^{89}$ in order to support the conclusion that arbitral tribunals created by bilateral investment treaties between Member States, at the expense of the ordinary judiciary, are not compatible with EU law. What underpins the ruling is the Court's belief that Member States should not disempower national courts.

${ }^{89}$ The Court refers to paras. 33 and 34 of AFSJ, supra n. 1. 
This is remarkable because, until very recently, the second subparagraph of Article 19(1) TEU had not played an important role in the case law of the Court ${ }^{90}$ and was seen merely as confirmation of the European mandate of national judges though the text of the provision does not even mention national courts. ${ }^{91}$ This may now be changing: the Court seems to be using Article 19 TEU to create the notion of a 'European judiciary' consisting of national judiciaries and the Court of Justice, which comes with the Member State obligation to ensure that national judges as EU judges remain independent, as affirmed in the Portuguese judges' case, but also that they not be disempowered.

Thanks to the recent decisions, it is now evident that while Member States are still largely free to organise their judiciaries in accordance with domestic preferences, they do so under the supervision of the Court of Justice. The determination of the bodies entrusted to decide on the interpretation and application of EU law is not, as it perhaps seemed to be in the past, a purely national matter. The determination must be made in compliance with Article 19 TEU, the principle of effective judicial protection and, more broadly, with the values of Article 2 TEU. For the time being, the Court has already made it clear that when a body operates as a court or tribunal, Member States are obliged to protect its judicial independence, and that Member States cannot remove disputes from the jurisdiction of their courts and tribunals. The future direction this line of case law will take is, however, yet to be determined.

\footnotetext{
${ }^{90}$ Court of Justice's Judge von Danwitz underlined in a recent speech that the interpretation given in the Portuguese case is 'the first substantive interpretation' of Art. 19 TEU: see T. von Danwitz: 'Values and the rule of law: Foundations of the European Union - an inside perspective from the ECJ', Lecture held at King's College London, 2 March 2018, available at <www.kcl.ac.uk/ law/research/centres/european/KingsCollege-London-TVD-k-def-Verteilung.pdf $>$, visited 31 July 2018. By way of example, Michal Bobek's chapter on the domestic application of EU law in a leading textbook devotes only a few lines on to the second subparagraph of Art. 19(1) TEU, see M. Bobek, 'The effects of EU law in the national legal systems', in C. Barnard and S. Peers, European Union Law, $2^{\text {nd }}$ edn (Oxford University Press 2018).

${ }^{91}$ See generally M. Claes, The National Courts'Mandate in the European Constitution (Hart 2006).
} 